\title{
ECOLOGICAL PURCHASES MADE BY MANAGERS IN HOTEL INDUSTRY. AN APPROACH OF THE MAIN DETERMINING FACTORS
}

\author{
Mirela Ştefănică ${ }^{1}$, Ana Iolanda Vodă르, Rodica Cristina Butnaru ${ }^{3}$, \\ Gina Ionela Butnaru ${ }^{4 *}$ and Mircea Gabriel Chirița ${ }^{5}$ \\ ${ }^{1224)}$ Alexandru Ioan Cuza University of Iaşi, Romania \\ ${ }^{3)}$ University of Quebec at Montreal, Canada \\ ${ }^{5)}$ University of Quebec at Rimouski, Canada
}

Please cite this article as:

Ştefănică, M., Vodă, A.I., Butnaru, R.C., Butnaru, G.I. and Chiriţa, M.G., 2020. Ecological Purchases Made by Managers in Hotel Industry. An Approach of the Main Determining Factors. Amfiteatru Economic, 22(53), pp. 57-70.

DOI 10.24818/EA/2019/53/57

\section{Article History}

Received: 29 September 2019

Revised: 23 November 2019

Accepted: 24 December 2019

\begin{abstract}
Lately, there has been an intensification of the concern for environmental protection and development of an ecological attitude and behaviour among the operators in tourism industry. Consequently, ecological purchases have become important components in establishing hotel environmental strategies and in the customers' consumption behaviour. Most of the researchers present this very attitude of the customers regarding the green products and their intention to buy them. The present research approaches ecological purchases from the hotel managers' perspective, by analysing the relationships among them, and the environmental attitude, environmental problems, and the benefits motivating the managers to make ecological purchases in 92 hotels in Romania. In this research we used the frequency analysis, scale reliability, and multiple linear regression analysis (the method of the least squares). The data were analysed with the help of STATA program, and the results support the research hypotheses, showing that the influence of the environmental attitude and of the economic benefits on ecological purchases is important. The results show a significant and positive relationship among the ecological purchases, the environmental attitude, and the associated benefits. In addition, the study identifies a negative relationship between the ecological purchases and the environmental concern. Furthermore, hotel classification has a negative influence on the ecological purchases made by their managers. The implications, limits, and future lines of research are also mentioned in this study.
\end{abstract}

Keywords: ecological purchases, environmental attitude, environmental problems, economic benefits, hotel business, Romania

JEL classification: Q50, L83, M10

* Corresponding author, Gina Ionela Butnaru - gina.butnaru@ uaic.ro 


\section{Introduction}

The major environmental unbalance perceived all over the world (climatic changes and global warming, pollution, biodiversity destruction, natural resource depletion and waste growth) has been studied by several researchers (Bennett, 2019). A growing environmental interest and concern is manifested also at the level of international forums, governments, several government and non-government organisations, either locally or internationally (EEA, 2012). They also determined the growing concern regarding environmental protection and the development of an ecological attitude and behaviour of the operators in tourism industry (Hilton 2018; Mariott 2018), in the context in which tourism industry is considered a major contributor to the environmental degradation and climatic changes (Su et al., 2013).

To be able to survive in a competitive business context, ecological management and green practices including ecological purchases have become important components for tourism and other industries (Alberini and Segerson, 2002). For this reason, Priego and Palacios (2008) state that ecological purchases should represent an important aspect in establishing hotel environmental strategies. Nevertheless, according to Brown (1996), the strategic decision that the hotel managers should purchase the products with a lower impact on the environment also depends on the benefits associated to them. Consequently, many hotel managers adopt ecological practices to build a competitive advantage by improving their image or reputation, which leads to the increase of customers' loyalty, while others pursue the reduction of consumption and of operational costs and obtaining economic and financial benefits.

Analysing the literature, we noticed that most of the researchers focus on the customers' attitude towards green products and their purchase intent (Wang et al., 2017), while this paper approaches a different perspective, i.e. hotel managers' behaviour regarding ecological purchases. Consequently, we will analyse the potential influence of some factors like environmental attitude, environmental concern, and importance of obtaining benefits on the behaviour of the managers in hotel industry regarding ecological purchases. For this purpose, we structured the article in the following sections: analysis of literature and development of research hypotheses, research methodology, results and discussions, preceded by introduction and followed by conclusions. The first part includes three subsections where we analysed the specialised literature according to the factors influencing the decision regarding ecological purchases. The second part, corresponding to the research methodology, offers information regarding the research method, the sampling, the description of the variables (dependent, independent, control variables). The final part includes the results and the conclusions of the research.

\section{Analysis of the literature and development of the research hypotheses}

\subsection{Influence of the environmental attitude on ecological purchases}

According to Wang et al. (2019), the attitude is the key factor affecting the consumers' purchase intent. The environmental attitude (ecological attitude) is manifested on three dimensions: cognitive, affective, and active (Diminescu, 2003), being a person's collection of beliefs, effects, and behavioural intents regarding environmental activities or problems 
(Schultz et al., 2004), and this attitude is frequently used to foresee the environmental behaviour (Kaiser et al., 1999).

Previous studies regarding ecological products and environmental behaviour supported the affirmation that there is a positive association between environmental attitude and ecological purchases (Yadav and Pathak, 2016). Therefore, ecological purchases are an important part of the environmental policy for many hotels (Priego and Palacios, 2008; Teng et al., 2012), however only a few of them report the practical actions or strategies regarding ecological purchases. Other studies regarding the relationship between the environmental attitude and the ecological purchases in the field of hotel industry in different areas of the world were developed by Rahman et al. (2012) by studies conducted in American hotels. Su et al. (2013), Wang (2012) and Teng et al. (2012) analysed green practices adopted in hotels in Taiwan, ecological purchases being included in the ten categories emphasised, and Bohdanowicz (2005), analysed the attitude of European hotel managers. Regarding the energetic efficiency, according to Teng et al. (2012), the success of the implementation of practices concerning power conservation in hotels and carbon emission reduction depends mainly on the management's support and on the personnel's implication. According to Wang et al. (2019), the attitude may influence the purchase of energetically efficient devices or equipment. The purchase of this equipment or of other technologies to minimise power consumption or the use of power regenerable sources (solar, geothermal sources) (Bohdanowicz, Zientara and Novotna, 2011) contributes to the improvement of energetic efficiency. Regarding the management supply, at present, many company operations are externalised to suppliers, and the environmental impact of a company is in growing connection with the environmental impact of their partners in the supply chain (Tate et al., 2012). However, companies may approach an ecological attitude by selecting ecological producers or suppliers, and by including certain contractual clauses on environmental aspects. The suppliers recognise the demand of "green" products and offer adequate alternatives. Taking into account the relevance of the influence of environmental attitude on ecological purchases, this study proposes to test the following hypothesis:

$\boldsymbol{H} \mathbf{1}$ - There is a direct and positive relationship between hotel managers' environmental attitude and their ecological purchases.

\subsection{The influence of the importance of obtaining benefits on the decision regarding hotel managers' ecological purchases}

The ecological practices adopted by the managers, as the purchase of products with low environmental impact, are often influenced by potential benefits associated to them (Brown, 1996). Consequently, many hotels apply environmental management practices to build a competitive advantage by improving their reputation, leading to the increase of their customers' loyalty. Some authors (Katris et al., 2015) analyse the stimulants motivating the hotel managers to adopt environmental management practices, ecological purchases included, and mention internal benefits (operational cost reduction), and external benefits (image, competitive advantage) to the implementation of environmental management. Operational cost reduction, meeting the demands of environmental-sensitive customers, and image improvement are stimulating factors for most of the hotel managers in Europe (Katris et al., 2015). The ecological performance of a hotel is extremely important for its 
competitive success (Kassinis and Soteriou, 2003), because most of the people are willing to pay more for the services of a hotel with ecological initiatives (Zhang et al., 2017), and according to Sreen et al. (2018), ecological purchases may highly contribute to obtain environmental performance and to create a positive public image, improving the competitive advantage (Carter, 2005). Chen (2008) observes that improvement of the green image of a company by the development of environmental performance helps opening new business opportunities and improves the competitive advantage. Ecological purchases leading for example to obtaining environmental accreditations/licences by the hotels contribute to the increase of their environmental commitment (Wouter Geerts, 2014). According to Chan (2013), the hotels adopting environmental strategies improve both their image and their reputation, and they will attract tourists with ecological concerns. Based on the studies mentioned above, we conclude that obtaining benefits represents a very important aspect in the decision-making process regarding ecological purchases made by hotel managers. Consequently, we formulated the following hypothesis:

H2 - The possibility of obtaining economic benefits significantly and positively influences ecological purchases made by the managers in hotel industry.

\subsection{The influence of hotel managers' environmental concern on ecological purchases}

Ecological purchases appeared as a result of global awareness regarding the growing number of environmental problems, determining the managers to consider them along with the social, ethical, and economic ones (Yook et al., 2018). It is well known that tourist activities have a strong impact on the environment, contributing to its degradation (e.g., destruction of biodiversity), also to the increase of greenhouse gas and carbon dioxide emissions (Pang et al., 2013). According to Lenzen et al. (2018), tourism represents approximately $8 \%$ of the global greenhouse gas emissions, the annual global carbon footprint of tourism increasing from 3.9 to 4.5 mil. tons $\mathrm{CO}_{2}$ equivalent between 2009 and 2013. According to Emission Gap Report of 2018, average EU emissions increased by $1 \%$ / year starting with 2014 (UNEP, 2018). Chen and Hung (2016) studied the awareness of environmental problems and they consider that it plays an important role in adopting and developing an ecological behaviour. Hotel managers have the possibility to initiate practices based on indicators of power conservation and carbon emission reduction. However, the results suggest that the success of the implementation of these indicators depends mainly on the hotel management's support of these practices, and on the personnel's implication (Teng et al., 2012). Taking into account the aspects mentioned in the literature, this study proposes to test the following hypothesis:

$\boldsymbol{H 3}$ - There is a direct and positive relationship between hotel managers' concern regarding the environmental impact on tourism and their ecological purchases.

\subsection{The influence of hotel classification on ecological purchases}

Generally, the hotels classified in the 1-3 star category do not have human resources and financial capacity for large-scale activities to take also into account the environmental protection, while from the 4-5 star hotels, only the ones with foreign investment, belonging to international hotel chains, have well defined environmental strategies (Baicu et al., 2019). According to the same authors, the managers of these hotels purchase ecological 
products, they save resources, recycle the waste, and use regenerable power (solar panels). Mungai and Irungu (2013) ascertained in a study conducted in Kenyan hotel industry that most of the 4-5 star hotels purchased efficient devices and equipment to reduce water consumption, ecological cleaning products, energetically efficient equipment, water treatment/purification installations, water taps with low flow and toilets with low drain volume. Among the environmental activities the least practised was composting organic kitchen waste. The results of a recent study conducted in Czech hotel industry demonstrated that these practices were adopted mainly by big hotels, with higher classification. The authors recommend the development of a mutual practice for hotel industry, generally adopted, the hotels with a lower number of stars included (Čech, Jindřichovská and Neubauer, 2019). The previous studies show the influence of hotel classification on ecological purchases in different countries. Consequently, in this study we proposed to test the following hypothesis:

$\boldsymbol{H 4}$ - There is a direct and negative relationship between the classification level of a hotel and ecological purchases made by its managers.

Synthesized, the conceptual research model and the hypotheses are presented in figure no. 1.

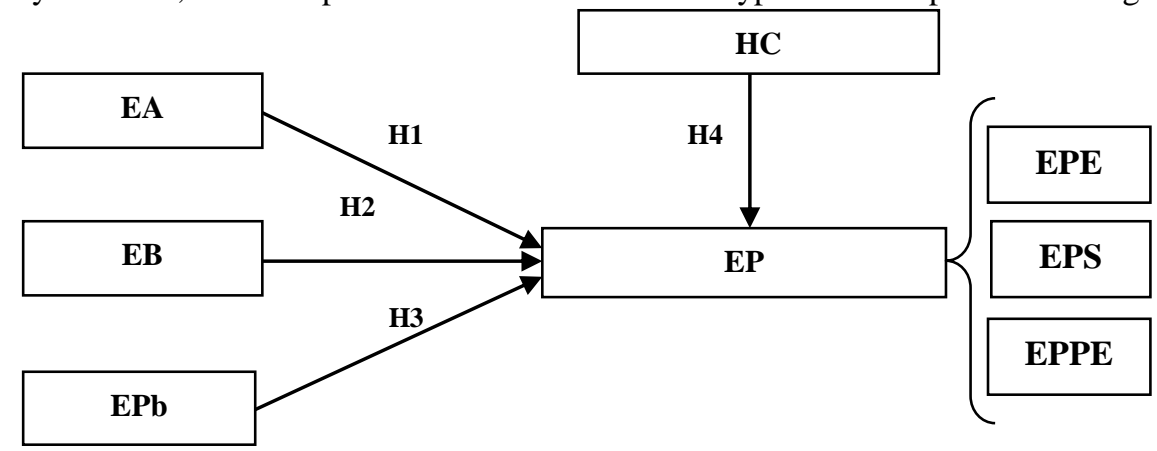

Figure no. 1: Conceptual model and hypotheses

where: EA - Environmental attitude, EB - Economic benefits, EPb - Environmental problems, HC - Hotel classification, EP - Ecological purchases, EPE - Purchases for improvement of energetic efficiency, EPS - Ecological purchases regarding suppliers/delivery of the goods, EPPE- Purchases made for pollutant emission reduction/compensation

\section{Research methodology}

\subsection{Research method}

The present study intends to analyse the relationship among ecological purchases, environmental attitude, environmental problems and benefits motivating the managers to make ecological purchases, within 92 hotels in Romania. The quantitative research method was performed based on the questionnaire, and the data were collected between March and July 2019. Within the research we used the frequency analysis, the reliability of the scale (tested by Cronbach's Alpha index), and validation of the hypotheses using the multiple linear regression analysis (the method of least squares). The statistical analysis was performed with the help of STATA statistical program, version 13.0. 
The relationship among the variables is modelled with the help of the multiple linear regression model, which will be as follows:

$\mathrm{EP}=\alpha+\beta_{1} \mathrm{EA}+\beta_{2} E B+\beta_{3} E P b+\beta_{4}$ Control $_{H C}+\xi$

where: EP - ecological purchases, dependent variable, EA - independent variable, measuring hotel managers' environmental attitude, EB - independent variable, expressing the importance of economic benefits, EP - independent variable, showing the concern of the managers in hotel industry regarding the environmental problems, Control ${ }_{H C}-$ clasificare hotel, control variable, $\alpha, \beta_{i}$ are the regression coefficients, where $\mathrm{i}=1,2, \ldots, 4$, $\xi$ is a residual variable.

\subsection{Sampling}

The sample is made of 92 hotel managers, who previously consented to answer the questions of the questionnaire. From the total of hotels analysed, $76.10 \%$ have $100 \%$ Romanian private capital as type of ownership, $10.90 \%$ have majoritarian Romanian private capital, 5,40\% have majoritarian foreign private capital, and $7.60 \%$ have $100 \%$ foreign capital. Regarding the hotel comfort category, most of the hotels have three stars $(48.90 \%)$ or four stars (38\%). Only $13 \%$ of the hotels have two or five stars. Most of the hotels included in the research have between 10 and 49 employees $(42.40 \%)$. The number of employees of $31.50 \%$ of the hotels is between 50 and 249 , and only $4.30 \%$ of the hotels have at least 250 employees.

\subsection{Description of variables}

Description of the dependent variable: ecological purchases (EP)

In the present study, in order to measure the ecological purchases (EP) we take into account the following: purchases made for the improvement of energetic efficiency (EPE); purchases made for pollutant emission reduction (EPPE), and those regarding supply modalities of purchased goods/services (ecological management) (EPS).

Purchases for improvement of energetic efficiency (EPE): 8 items were used to evaluate the purchases made with the purpose to improve the energetic efficiency. We considered the following purchases: power consumption monitoring devices, ecological materials for thermal insulation, etc. (table no. 2). Each item is encoded with the value " 1 " for an affirmative answer and " 0 " for the negative one.

Purchases made for pollutant emission reduction/compensation (EPPE): The items of the questionnaire measuring the purchases made for the pollutant emission reduction/compensation are as follows: "For pollutant emission reduction, are you willing to compensate $\mathrm{CO}_{2}$ emissions by paying a fee?" and "For pollutant emission reduction, are you willing to compensate $\mathrm{CO}_{2}$ emissions by donations for ecological projects?" (table no. 1). The values established for the answers at the items of the questionnaire are: " 1 " for "Yes", and "0" for "No".

Ecological purchases regarding suppliers/delivery of the goods (EPS): The items of the questionnaire measuring EPS are as follows: 5 items were used for the evaluation of this 
category of ecological purchases (table no. 1). Each item is encoded with the value "1" for an affirmative answer and " 0 " for the negative one.

The score for ecological purchases (EP) was determined based on the following equation:

$$
\left.\left.\left.E P=\left(\left(\sum_{i=1}^{8} E P E_{i}\right) / 8\right)+\left(\sum_{i=1}^{2} E P P E_{i}\right) / 2\right)+\left(\sum_{i=1}^{5} E P S_{i}\right) / 5\right)\right)
$$

Table no. 1: Classification of dimensions and item description for the dependent variable

\begin{tabular}{|c|c|c|c|c|}
\hline & Dimensions & Questions from the questionnaire & Items & Abbreviation \\
\hline \multirow{15}{*}{ EP } & \multirow{8}{*}{ EPE } & $\begin{array}{l}\text { Have you purchased devices to monitor power } \\
\text { consumption? }\end{array}$ & Q14_1 & EPE_1 \\
\hline & & $\begin{array}{l}\text { Have you purchased ecological materials for } \\
\text { thermal insulation? }\end{array}$ & Q14_3 & EPE_2 \\
\hline & & $\begin{array}{l}\text { Have you purchased energetically efficient } \\
\text { heating system - ventilation and air conditioned? }\end{array}$ & Q14_5 & EPE_3 \\
\hline & & Have you purchased thermostats? & Q14_6 & EPE_4 \\
\hline & & $\begin{array}{l}\text { Have you purchased energetically efficient } \\
\text { illuminating systems? }\end{array}$ & Q16_2 & EPE_5 \\
\hline & & $\begin{array}{l}\text { Have you purchased motion sensors, timers, } \\
\text { potentiometers? }\end{array}$ & Q16_3 & EPE_6 \\
\hline & & $\begin{array}{l}\text { Have you purchased systems/equipment to } \\
\text { produce alternative power (solar, photovoltaic, } \\
\text { geothermal, biogas power)? }\end{array}$ & Q15_1 & EPE_7 \\
\hline & & $\begin{array}{l}\text { Have you purchased delivery services of } \\
\text { alternative power from a supplier with an active } \\
\text { policy in the field of alternative power sources? }\end{array}$ & Q15_6 & EPE_8 \\
\hline & \multirow{2}{*}{ EPPE } & $\begin{array}{l}\text { Are you willing to compensate } \mathrm{CO}_{2} \text { emissions by } \\
\text { paying a fee? }\end{array}$ & Q24_2 & EPPE_1 \\
\hline & & $\begin{array}{l}\text { Are you willing to compensate } \mathrm{CO}_{2} \text { emissions by } \\
\text { donations for ecological projects? }\end{array}$ & Q24_4 & EPPE_2 \\
\hline & \multirow{5}{*}{ EPS } & $\begin{array}{l}\text { Is the purchase of ecological products a current } \\
\text { policy of the hotel? }\end{array}$ & Q25_1 & EPS_1 \\
\hline & & $\begin{array}{l}\text { Are ecological aspects considered when you } \\
\text { decide to contact a supplier? }\end{array}$ & Q25_2 & EPS_2 \\
\hline & & $\begin{array}{l}\text { Are there any clauses in your agreements with } \\
\text { suppliers by which to require the use of minimum } \\
\text { packaging? }\end{array}$ & Q25_3 & EPS_3 \\
\hline & & $\begin{array}{l}\text { Are there any clauses in your agreements with } \\
\text { suppliers by which to require transportation of the } \\
\text { goods in a least polluting manner? }\end{array}$ & Q25_4 & EPS_4 \\
\hline & & $\begin{array}{l}\text { Are there any concerns for your hotel regarding } \\
\text { the assimilation of environmental-friendly } \\
\text { technologies? }\end{array}$ & Q12_5 & EPS_5 \\
\hline
\end{tabular}

Description of independent variables

a. Hotel managers' environmental attitude (EA) - the independent variable EA measures hotel managers' environmental attitude by ecological policies and strategies adopted. Consequently, to measure the environmental policy adopted (EAEP), the respondents were asked if the environmental policy or the declaration of environmental policy was 
permanently adapted to the environmental legislation in force. The variable is encoded with the value " 1 " for an affirmative answer and with " 0 " for a negative one. To measure ecological strategies of the hotels (EAES), 7 items of the questionnaire were used. The questions lead to strategies of efficient waste management, strategies of pollutant emission reduction, etc. (table no. 2). The values for each item are " 1 " (if the answer is positive) and " 0 " (if it is negative). The score for the environmental attitude (EA) was determined based on the following equation:

$$
E A=E A E P+\left(\left(\sum_{i=1}^{7} E A E S_{i}\right) / 7\right)
$$

Table no. 2: Classification of dimensions and item description for the independent and control variables

\begin{tabular}{|c|c|c|c|c|}
\hline & Dimensions & Questions from the questionnaire & Items & Abbreviation \\
\hline \multirow{8}{*}{ EA } & EAEP & $\begin{array}{l}\text { Does your hotel have an active environmental } \\
\text { policy which is permanently adapted to the } \\
\text { environmental legislation in force? }\end{array}$ & Q9_4 & EAEP \\
\hline & \multirow{7}{*}{ EAES } & $\begin{array}{l}\text { Are strategies of environmental protection set in } \\
\text { the hotel? }\end{array}$ & Q 10 & EAES_1 \\
\hline & & $\begin{array}{l}\text { Is efficient waste management a current strategy } \\
\text { of the hotel? }\end{array}$ & Q 12_1 & EAES_2 \\
\hline & & $\begin{array}{l}\text { Is pollutant emission reduction a current strategy } \\
\text { of the hotel? }\end{array}$ & Q 12_2 & EAES_3 \\
\hline & & $\begin{array}{l}\text { Improvement of energetic efficiency is a current } \\
\text { strategy of the hotel? }\end{array}$ & Q 12_3 & EAES_4 \\
\hline & & $\begin{array}{l}\text { Is water consumption reduction a current strategy } \\
\text { of the hotel? }\end{array}$ & Q 12_4 & EAES_5 \\
\hline & & $\begin{array}{l}\text { Is the purchase of ecological products or } \\
\text { equipment a current strategy of the hotel? }\end{array}$ & Q 12_6 & EAES_6 \\
\hline & & Is noise reduction a current strategy of the hotel? & Q 12_7 & EAES_7 \\
\hline EB & - & $\begin{array}{l}\text { Does obtaining economic and financial benefits } \\
\text { determine you to make ecological purchases? }\end{array}$ & Q28_1 & EB \\
\hline EP & - & $\begin{array}{l}\text { Do the current environmental problems determine } \\
\text { you to make ecological purchases? }\end{array}$ & Q2_6 & EP \\
\hline
\end{tabular}

b. Economic benefits $(E B)$ - To measure economic benefits, the respondent had to answer the following question of the questionnaire: "Does the possibility of obtaining economic benefits determine you to make ecological purchases?". The respondent was asked to select one of the answer alternatives: $1=$ "Yes", and $0=$ "No".

c. Environmental problems (environmental concern) (EPb) - To measure this indicator, we used the following question of the questionnaire: "Do the actual environmental problems determine you to make ecological purchases?". The respondent was asked to select one of the answer alternatives: $1=$ "Yes" and $0=$ "No".

\section{Description of the control variable}

In the present study, the control variable taken into account is Hotel Classification (HC): 1- two stars (HC_1); 2 - three stars (HC_2); 3 - four stars (HC_3) and 4 - five stars (HC_4) (table no. 3). 
Table no. 3: Description of control variable

\begin{tabular}{|c|c|l|c|c|}
\hline & Dimensions & \multicolumn{1}{|c|}{ Questions from the questionnaire } & Items & Abbreviation \\
\hline HC & - & $\begin{array}{l}\text { According to the comfort category, your hotel } \\
\text { has: a) 2 stars; b) 3 stars; c) 4 stars; d) 5 stars }\end{array}$ & Q33 & Control $_{\mathrm{HC}}$ \\
\hline
\end{tabular}

\section{Results and discussions}

To measure the reliability of the scales of compound indicators and the validation of internal consistency of indicators we used Cronbach Alpha score. In the case of the sample analysed, Cronbach's Alpha records values over the minimum threshold indicated as follows: 0.878 for EP and 0.841 for EA. (Table no. 4)

Table no. 4: Testing and validation of constructs

\begin{tabular}{|l|c|c|}
\hline Construct/dimensions & Number of questions & Cronbach's Alpha \\
\hline Ecological purchases (EP) & 15 & 0.878 \\
\hline Environmental attitude (EA) & 7 & 0.841 \\
\hline Economic benefits (EB) & 1 & - \\
\hline Environmental problems (EPb) & 1 & - \\
\hline
\end{tabular}

The parameters of linear regression models are estimated with the help of the method of least squares. The results of data processing in STATA are presented in table no. 5.

Table no. 5: Regression results

\begin{tabular}{|c|c|c|c|c|}
\hline Variables & \multicolumn{2}{|c|}{$\begin{array}{c}\text { Model } 1 \text { - OLS } \\
\text { Dependent variable EP }\end{array}$} & \multicolumn{2}{|c|}{$\begin{array}{c}\text { Model 2 - OLS } \\
\text { Dependent variable EP }\end{array}$} \\
\hline \multicolumn{5}{|l|}{ Independent var. } \\
\hline & Coeff. & $\mathrm{P}>|\mathrm{t}|$ & Coeff. & $\mathrm{P}>|\mathrm{t}|$ \\
\hline EA & $0.414(* * * *)$ & 0.000 & $0.393(* * * *)$ & 0.000 \\
\hline EB & $0.156(* * * *)$ & 0.007 & $0.111(* *)$ & 0.061 \\
\hline $\mathbf{E P b}$ & $-0.190(* *)$ & 0.079 & $-0.158(*)$ & 0.144 \\
\hline HC_2 & & & $-0.133(* *)$ & 0.282 \\
\hline $\mathrm{HC}_{-} 3$ & & & $-0.212(* *)$ & 0.084 \\
\hline HC_4 & & & $-0.323(* * *)$ & 0.025 \\
\hline Const. & $0.385(* * * *)$ & 0.000 & $0.609(* * * *)$ & 0.000 \\
\hline $\mathbf{R}^{2}$ & \multicolumn{2}{|c|}{0.423} & \multicolumn{2}{|c|}{0.403} \\
\hline $\mathbf{R}^{2}$ adjusted & \multicolumn{2}{|c|}{0.465} & \multicolumn{2}{|c|}{0.427} \\
\hline
\end{tabular}

Note: $*, * *, * * *, * * * *$ show that the coefficients are significant at the level of $15 \%, 10 \%, 5 \%$ și $1 \%$.

In model 1 , the value of the determination report $(\mathrm{R}$ square $=0.667)$ indicates that $42.30 \%$ of the variation of ecological purchases is due to the simultaneous influence of the environmental attitude, economic benefits and environmental concern. The value of test $\mathrm{F}$ (21.52) and the associated significance level shows that the independent variables of the model have a significant influence on ecological purchases in the context of $10 \%$ assumed risk. We can see that at the specific regression coefficients, the level of significance ( $\mathrm{P}$ value) is lower than 0.05 , indicating that the influence of the hotel managers' environmental attitude (EA) and of the economic benefits (EB) on the ecological purchases (EP) is significant in the context of 5\% assumed risk. Consequently, the value of the coefficient corresponding to the variable environmental attitude (EA) is 0.414 , so at a growth of EA by 
one unit there will be an average growth of EP by 0.414 units if $\mathrm{EB}$ and $\mathrm{EPb}$ are maintained constant. The coefficient corresponding to the variable economic benefits (EB) is 0.156 , which means that the average growth of ecological purchases (EP) is by 0.156 units when the hotel managers' environmental attitude grows by one unit, and the variation of the other variables is constant. We can see that $\mathrm{P}$-value $=0.000<0.05$, therefore this coefficient is significantly different from 0 . The value of the coefficient corresponding to the independent variable environmental problems $(\mathrm{EPb})$ is -0.190 , so at a growth of the variable economic benefits (EB) by one unit there will be an average decrease of ecological purchases (EP) by 0.190 units when the other variables of the model are constant. Since P-value $=0.079$, this coefficient is significant for $10 \%$ assumed risk.

Based on the data of table no. 5 and on the values of the coefficients, the estimated multiple linear regression model, which resulted from the analysis, is the following:

$\mathrm{EP}=0.385+0.414 * \mathrm{EA}+0.156 * \mathrm{~EB}-0.190 * \mathrm{EPb}$

Consequently, we may conclude that, in the case studied, the influence of environmental attitude and of economic benefits on ecological purchases is important. Furthermore, the significant and positive connection among ecological purchases, environmental attitude, and associated benefits leads us to the validation of the two hypotheses proposed: $\mathrm{H} 1$ and H2. Similar results were also obtained in the studies conducted by Yadav and Pathak (2016). The relationship between ecological purchases and environmental concern is significant and negative, for $10 \%$ assumed risk, which allows us to invalidate the hypothesis H3. These results contradict some previous empirical studies of the literature showing that the hotels adopting an environmental strategy are also concerned with the implementation of programmes to reduce pollutant emissions and to protect the environment (Chan, 2013; Chen and Hung, 2016).

In model 2 , the value of the determination report $\mathrm{R}$ square is 0.465 , meaning that $46.50 \%$ of the variation of the ecological purchases may be explained with the help of the independent variables included in the analysis. The adjusted determination report (adjusted $R$-square) emphasises that 0.427 of the total variation is due to the regression line, taking into account the corresponding degrees of freedom. The value of test F (12.32) and of the threshold of significance $(0.000<0.15)$ shows that the regression model constructed explains the dependence of the variables by a linear and significant connection, for $15 \%$ assumed risk. The value of the coefficient corresponding to the influence of the variable environmental attitude shows that at a growth by one unit of its level, the level of the variable ecological purchases will have an average growth by 0.393 units, and when the variations of the other variables of the model are constant. The coefficient corresponding to the variable economic benefits is 0.111 , which means that the level of the ecological purchases coefficient has an average growth by 0.111 units when the economic benefits grow by one unit, and the rest of the variables are constant. The value corresponding to the coefficient of the variable environmental problems $(\mathrm{EPb})$ indicates that at a growth by one unit of its level, the coefficient of the ecological purchases will have an average decrease by 0.112 units in the context of $15 \%$ risk, and of constant variation of the independent variables of the model. Compared to the previous model, we also took into account the hotel classification as control variable. Consequently, all three categories of hotels have a negative influence on the dependent variable, but only 3 and 4 star hotels have a significant relationship, which allows us to partially validate hypothesis H4. Similar results were also obtained in the 
studies conducted by Mungai and Irungu (2013), Baicu et al. (2019), Čech, Jindřichovská și Neubauer (2019).

Model 2 of multiple linear regression is the following:

$\mathrm{EP}=0.609+0.393 * \mathrm{EA}+0.111 * \mathrm{~EB}-0.158 * \mathrm{EPb}-0.133 * \mathrm{HC} \_2-0.212 * \mathrm{HC} \_3-0.323 * \mathrm{HC} \_4$

To test error normality, we used Jarque-Bera test, and for error heteroscedasticity, we used Breusch-Pagan test. We can see in table no. 6 that Prob. values are between 0.126 and $0.132>\alpha=0.05$, so the residual variable follows a normal distribution law for each of the two models presented. Breusch-Pagan test shows that the values of probabilities associated to this test corresponding to each model (Prob $=0.070$ (Model 1) and 0.053 (Model 2)) are higher than $\alpha=0.05$, so the residual variables resulted of each model are homoscedastic.

Table no. 6: Normality and heteroscedasticity test

\begin{tabular}{|l|c|c|}
\hline & Model (1) & Model (2) \\
\hline Normality test (Jarque-Bera) & 4.084 & 4.152 \\
\hline Prob. & 0.132 & 0.126 \\
\hline Heteroscedasticity test (Breusch-Pagan) & 0.320 & 3.70 \\
\hline Prob. & 0.070 & 0.053 \\
\hline
\end{tabular}

\section{Conclusions}

Though ecological purchase is a relatively new concept for many businesses, there are top companies which have already implemented ecological processes, because they are aware of their social and environmental responsibility (Yook et al., 2018). Environmental concern is a growingly frequent concern for the managers in hotel industry. Their initiative to meet the European standards regarding environmental protection by ecological purchases is also animated by obtaining benefits. The study presents an analysis from the perspective of the behaviour regarding ecological purchases made by hotel managers and not by customers, as most studies in hotel industry show, thus making a difference. The objective of this research is to identify the influence of some factors like environmental attitude, environmental concern, and importance of obtaining benefits, on the behaviour of Romanian managers in hotel industry regarding ecological purchases. The results demonstrate that there is a significant and positive connection between the environmental attitude of hotel managers in Romania and the types of ecological purchases.

This study has practical implications and contributes to the development of hotel managers' degree of awareness regarding ecological purchases, internal and external benefits which may be obtained. It seems that the benefits stimulating the most the hotel managers in Europe are operational cost reduction, meeting the demands of environment-sensitive customers, and image improvement (Katris et al., 2015). Environmental attitude and behaviour and initiatives of Romanian hotel managers should be also supported and encouraged by the government policies at national level.

This research presents some limits, among which the size of the sample. The analysis was performed on 92 hotels. On the other hand, the conceptual frame considers three independent variables (hotel managers' environmental attitude (EA), economic benefits 
(EB), and environmental problems (environmental concern) (EPb)), and only one control variable (hotel classification (HC)) in connection with the process of ecological purchases.

This analysis could be extended to the level of hotel industry in EU28 countries, which would explain the behaviour of European managers in hotel industry regarding ecological purchases with the help of independent variables considered in this study and mentioned above. The results could serve as leads in the process of sensitisation at the level of hotel management and at national level in formulating government policies in Romania, with the purpose that hotel industry meet the international standards.

\section{Acknowledgement}

"This project is financed by the Ministry of Research and Innovation by Program 1 Development of research-development national system, Subprogram 1.2 - Institutional performance - Projects to finance the excellence in CDI, Contract No. 34PFE/19.10.2018"

\section{References}

Alberini, A. and Segerson, K., 2002. Assessing voluntary programs to improve environmental quality. Environmental and Resource Economics, 22(1-2), pp. 157-184.

Barbarossa, C. and De Pelsmacker, P., 2016. Positive and negative antecedents of purchasing eco-friendly products: A comparison between green and non-green consumers. Journal of Business Ethics, 134(2), pp. 229-247.

Bennett, G., 2019. Dilemmas: coping with environmental problems. London: Routledge.

Bohdanowicz, P., 2005. European hoteliers' environmental attitudes: Greening the business. The Cornell Hotel and Restaurant Administration Quarterly, [e-journal] 46, pp. 188-204. https://doi.org/10.1177/0010880404273891.

Bohdanowicz, P., Zientara, P. and Novotna, E., 2011. International hotel chains and environmental protection: an analysis of Hilton's we care! programme (Europe, 2006-2008). Journal of Sustainable Tourism, 19(7), pp. 797-816.

Brown, M., 1996. Environmental policy in the hotel sector: "green" strategy or stratagem?. International Journal of Contemporary Hospitality Management, [e-journal] 8(3), pp. 18-23. https://doi.org/10.1108/09596119610115961.

Carter, C., 2005. Purchasing social responsibility and firm performance. International Journal of Physical, Distribution \& Logistic Management, [e-journal] 35(3), pp. 177-194. https://doi.org/10.1108/09600030510594567.

Chan, E.S.W., 2013. Managing green marketing: Hong Kong hotel managers' perspective. International Journal of Hospitality Management, 34, pp. 442-461.

Chen, S.C. and Hung C.W., 2016. Elucidating the factors influencing the acceptance of green products: An extension of theory of planned behavior. Technological Forecasting and Social Change, [e-journal] 112, pp. 155-163. https://doi.org/10.1016/ j.techfore.2016.08.022.

Chen, Y.S., 2008. The Driver of Green Innovation and Green Image - Green Core Competence. Journal of Business Ethics, [e-journal] 81, pp. 531-543. https://doi.org/ 10.1007/s10551-007-9522-1. 
Čech, P., Jindřichovská, I. and Neubauer, J., 2019. Achieving a great reputation for corporate social responsibility: study from the czech hospitality industry. Scientific Papers of the University of Pardubice, 27(45), pp. 17-28.

Diminescu, N., 2003. Descoperă natura de la informaţie la atitudine şi comportament ecologic. Timişoara: Mirton.

European Environment Agency (EEA), 2012. Consumption and the Environment. [online] Available at: <http://www.eea.europa.eu/publications/consumption-and-theenvironment-2012.pdf> [Accessed 31July 2019].

Geerts, W., 2014. Environmental certification schemes: Hotel managers' views and perceptions. International Journal of Hospitality Management, 39, pp. 87-96.

Hameed, I., Waris, I. and Amin ul Haq, M., 2019. Predicting eco-conscious consumer behavior using theory of planned behavior in Pakistan. Environmental Science and Pollution Research, [e-journal] 26, pp. 15535-15547. https://doi.org/10.1007/s11356019-04967-9.

Hilton, 2018. Environmental Impact. [online] Available at: <https://cr.hilton.com/ environment/> [Accessed 12 August 2019].

Kaiser, F.G., Ranney, M., Hartig, T. and Bowler, P.A., 1999. Ecological behavior, environmental attitude, and feelings of responsibility for the environment. European psychologist, 4(2), p. 59.

Kassinis, G.I. and Soteriou, A.C., 2003. Greening the service profit chain: The impact of environmental management practices. Production and operations Management, 12(3), pp. 386-403.

Katris, G., Kyrikou, E. and Bentsou, D., 2015. The importance of environmental management and the benefits of its implementing both for large as well as for medium and smallsized hotel units. Proceedings of the 14th International Conference on Environmental Science and Technology. [online] Available at: <https://cest2015. gnest.org/papers/cest2015_00573_oral_paper.pdf> [Accessed 14 August 2019].

Lenzen, M., Sun, Y.-Y., Faturay, F., Ting, Y.-P., Geschke, A. and Malik, A., 2018. The carbon foot print of global tourism. Nature Climate Change, [e-journal] 8, pp. 522-528. https://doi.org/10.1038/s41558-018-0141-x.

Marriott International, 2018. 2018 Sustainability Highlights. [online] Available at: <http://serve360.marriott.com/wpcontent/uploads/2018/10/2018_Serve_360_Report.pdf.> [Accessed 10 August 2019].

Mungai, M. and Irungu, R., 2013. An Assessment of Management Commitment to Application of Green Practices in 4-5 Star Hotels in Mombasa, Kenya. Information and Knowledge Management, 3(6), pp.40-47.

Pang, S.F.H., McKercher, B. and Prideaux B., 2013. Climate Change and Tourism: An Overview. Asia Pacific Journal of Tourism Research,18(1-2), pp. 4-20.

Priego, B.M.J. and Palacios, A.C., 2008. Analysis of environmental statements issued by EMAS-certified Spanish hotels. Cornell Hospitality Quarterly, 49(4), pp. 381-394.

Rahman, I., Reynolds, D. and Svaren, S.,2012. How "green" are North American hotels? An exploration of low-cost adoption practices. International Journal of Hospitality Management, [e-journal] 31(3), pp.720-727. https://doi.org/10.1016/j.ijhm.2011.09.008. 
Schultz, P.W., Shriver, C., Tabanico, J.J. and Khazian, A.M., 2004. Implicit connections with nature. Journal of environmental psychology, 24(1), pp. 31-42.

Su, Y.P., Hall, C.M. and Ozanne, L., 2013. Hospitality industry responses to climate change: A benchmark study of Taiwanese tourist hotels. Asia Pacific Journal of Tourism Research, 18(1-2), pp. 92-107.

Sreen, N., Purbey, S. and Sadarangani, P., 2018. Impact of culture, behavior and gender on green purchase intention. Journal of Retailing and Consumer Services, [e-journal] 41, pp.177-189. https://doi.org/10.1016/j.jretconser.2017.12.002 .

Tate, W.L., Ellram, L.M. and Dooley, K.J., 2012. Environmental purchasing and supplier management (EPSM): Theory and practice. Journal of Purchasing and Supply Management, 18(3), pp.173-188. https://doi.org/10.1016/j.pursup.2012.07.001.

Teng, C.C., Horng, J.S., Hu, M.L.M., Chien, L.H. and Shen, Y.C., 2012. Developing energy conservation and carbon reduction indicators for the hotel industry in Taiwan. International Journal of Hospitality Management, 31(1), pp. 199-208.

United Nations Environment Programme (UNEP), 2018. Emissions Gap Report. [online] Available at: <http://wedocs.unep.org/bitstream/handle/20.500.11822/26895/EGR2018_ FullReport_EN.pdf> [Accessed 30 August 2019].

Wang, R., 2012. The Investigation of Green Best Practices for Hotels in Taiwan. Procedia - Social and Behavioral Sciences, [e-journal] 57, pp. 140-145. https://doi.org/10.1016/ j.sbspro.2012.09.1167.

Wang, J., Wang, S., Wang, Y., Li, J. and Zhao, D., 2018. Extending the theory of planned behavior to understand consumers' intentions to visit green hotels in the Chinese context. International Journal of Contemporary Hospitality Management, [e-journal] 30(8), pp. 2810-2825. https://doi.org/10.1108/IJCHM-04-2017-0223.

Wang, Z., Sun, Q., Wang, B. and Zhang, B., 2019. Purchasing intentions of Chinese consumers on energy-efficient appliances: Is the energy efficiency label effective?. Journal of Cleaner Production, [e-journal] 238, article 117896. https://doi.org/ 10.1016/j.jclepro.2019.117896.

Yadav, R. and Pathak, G.S., 2017. Determinants of Consumers' Green Purchase Behavior in a Developing Nation: Applying and Extending the Theory of Planned Behavior. Ecological Economics, [e-journal] 134, pp. 114-122. https://doi.org/10.1016/ j.ecolecon.2016.12.019.

Yook, K.H., Choi, J.H. and Suresh, N.C., 2018. Linking green purchasing capabilities to environmental and economic performance: The moderating role of firmsize. Journal of Purchasing and Supply Management, [e-journal] 24(4), pp. 326-337. https://doi.org/ 10.1016/j.pursup.2017.09.001.

Zhang, L., Wu, J., Liu, H. and Zhang, X., 2017. The value of going green in the hotel industry: evidence from Beijing. Real Estate Economics, [e-journal] V, pp. 1-26. https://doi.org/10.1111/1540-6229.12225. 